\title{
Northern Togo and the world economy
}

\author{
HENK REITSMA \\ AND \\ LEO DE HAAN
}

\begin{abstract}
Department of Human Geography, University of Amsterdam, $1018 \mathrm{VZ}$ Amsterdam, The Netherlands
\end{abstract}

\begin{abstract}
ABSTRACr. How global is the world economy? Does it also encompass the remote corners of the Third World where subsistence agriculture still predominates and where the first hard-surface roads have yet to be built? And if it does, when did these areas become incorporated into the world economy? Whereas by 1919 northernmost Togo had hardly any economic contacts with the outside world, the impact which the Great Depression had on it serves as evidence that only 10 years later this rural periphery had lost part of its former isolated, self-sufficient existence. Since then, capitalist penetration has made further inroads into the area. With most other Third-World 'backwaters' having experienced similar developments since the turn of the century, today's world economy does appear to be one globe-spanning, interdependent system.
\end{abstract}

\section{Initial impressions}

During a brief visit to the rural areas of northernmost Togo, we might well conclude that this remote corner of Africa is not integrated in the capitalist world economy. The local population-mainly Gourma, Moba and Ngam Ngam - lives for the most part in small, dispersed villages of a few hundred inhabitants. Although every household possesses some livestock-cattle, goats, sheep, chickens and/or guinea fowl-subsistence-crop farming is the dominant economic activity for most villagers. The major food crops are various types of millet and sorghum, and yams. Other crops include corn (or maize), rice, cassava, tomatoes, peppers, beans (especially Vigna unguiculata), peanuts (or groundnuts), gombo (Abelmoschus), sweet potatoes, and a local eggplant variety (Solamim aethiopicum). Simple, traditional methods of production prevail, including the use of the hoe; and irrigation plays practically no role.

Children make up approximately half the population, resulting in an extremely low average age. Nearly all adults are illiterate, and at best one quarter of the children receives an education. Except for a few local government officials, no one works for wages. People have hardly any (modern) material possessions, are poorly housed and dressed, and live almost completely outside a money-economy. Or, so it seems. 
Apart from the road from Lomé to Burkina Faso, there are only dirt roads and footpaths, making the smaller villages all but inaccessible during the rainy season. As might be expected, there is no electricity in the villages and thus no telephone service. Medical facilities are not only elementary, but few and far between. Nearly all (hand-dug) wells dry up in the course of the dry season, causing shortages of clean drinking water. Outside the small market centers, there are almost no stores, and those which do exist sell only a very limited selection of goods. Modern forms of social security, such as pension plans, unemployment insurance, and disability payments are unheard of. Employment outside the agricultural sector consists merely of some beer brewing, pottery making, and a little local trading.

Human existence is rather precarious, with most people being poorly nourished and occasionally even going hungry. In view of the ongoing deterioration of the physical environment, living conditions are unlikely to improve in coming years. Originally a woodland savanna with many shrubs, the landscape is acquiring more and more a steppe-like appearance with only widely scattered trees. Before long, much of the area can be expected to suffer a serious shortage of fuelwood-virtually the only source of energy available in the region. Food security and mere survival are increasingly endangered as the population expands and the carrying capacity of the land is being literally eroded away.

\section{How global is the world economy?}

Assuming, for the sake of argument, that our description of rural life in northern Togo is a reasonably accurate portrayal of reality, and taking into consideration that similar descriptions are possible for a great many other rural areas in the Third World, above all in sub-Saharan Africa, one may question the existence of a global economic system. In other words, are Wallerstein (e.g., 1976a, 1979) and other advocates of a world-system perspective (e.g., Chirot, 1977; Taylor, 1985, 1986, 1988) mistaken? It is really true, as they suggest, that all, or nearly all, places on earth are integrated-and have been integrated for quite some time-in a worldwide network of interdependent economic relations? Do international flows of raw materials, manufactured goods and capital, together with movements of (migrant) labor, business managers, economic advisers and know-how, truly link all parts of the world to virtually all others? And is the world-system approach meaningful for gaining insight into the problems and possibilities of the more isolated and underdeveloped areas of the world? ${ }^{1}$

Presumably everyone agrees that the economies of the developed countries are thoroughly intertwined and thus heavily dependent on one another. Much the same can be said about the urbanized and industrialized sections of the less-developed countries, and about those Third-world areas where mining activities or agricultural production for export are important. But how about the more remote and comparatively backward, rural areas of North Togo and similar places, where most people-mainly subsistence farmers-are more than an hour's walk from the nearest road? Are the lives and material well-being of these farmers (noticeably) affected by decisions made in New York, Tokyo, Paris or London, by Kondratieff waves or by 'worldwide' economic recessions?

The purpose of this article is to shed some light on these issues by looking more closely at the ways in which the villagers of North Togo provide for their livelihood. First, the present situation will be discussed. In a later section, attention will be focused on an earlier period in an attempt to pinpoint when the area started to become integrated into the global economic system. 


\section{Northern Togo revisited (1991)}

The description given in the introductory section of this paper may be said to be based on rather cursory impressions during a first visit to the area. Although basically not incorrect, it is incomplete and thus a little misleading simply because certain things easily go unnoticed. For example, it is not until after having spent some time in the villages that one becones aware that there are relatively few men in the 15-35 year age-group. Upon inquiry, one learns that many young men-on average about 15 percent, but locally as much as 25 percent-are away as migrant laborers, temporarily working in Ghana, Côte d'lvoire or Nigeria, or in the capital city of Lomé. About one out of every four labor migrants regularly sends part of his earnings to his relatives, while nearly all of them bring home some cash as well as miscellaneous consumer goods-including watches, radios, flashlights, bikes, and even beds, mattresses and corrugated iron-every time they return to their villages after having been away for a few months or a considerably longer period of time.

Some of the money in the villages is derived from occasional sales of livestock and poultry to urban markets in the country. These sales tend to be particularly large in unusually dry years, when farmers need to supplement their exceptionally meager cash-crop earnings. An added reason-at least for the few semi-nomadic Fulani (or Fulbe) in the area-is that there may not be enough forage available to keep all, or even most, animals alive.

Despite the relative inaccessibility of the area and the long distance to the coast $(c$. $600 \mathrm{~km}$ or 370 miles), many farmers use part of their land for growing commercial crops. Most important, by far, are cotton and peanuts. Whereas the cotton is exported, the entire peanut crop is sold on the rapidly expanding domestic market. Prior to 1980, the peanuts, too, were grown for export. Like the colonial authorities in bygone days, the government of Togo encourages the production of these two cash crops in the North. Although they occupy a rather small proportion of all cultivated land, cotton and peanuts are the major (and often only) sources of monetary income for many households. Less important crops grown for sale are beans and vegetables, both destined for the country's urban markets.

Finally, part of the money circulating in northern Togo is brought in by salaried administrators and teachers, foreign and Togolese development experts, agricultural advisers, and by employees of SOTOCO (National Cotton Board).

Clearly, then, there is more than unpaid subsistence production, even though hardly any wage labor can be found in the rural areas. In addition to the sources of cash income just mentioned, some women earn a little money brewing sorghum beer or making pottery, while a few others are self-employed in local trade. All in all, no household lives entirely outside the modern money-economy; according to our calculations, per capita income amounts to about 60 or 70 US dollars a year. Among the most conspicuous signs that life in rural North Togo is affected by outside influences are the roofs of many huts, made as they are of corrugated iron. Besides, the people use imported chemical fertilizer, wear imported clothes, and have various other consumer goods which they themselves have not manufactured.

\section{North Togo on the eve of the Big Crash}

Now that we know that Togo's northern periphery forms an (as yet weakly) integrated part of the world economy, we may wonder when and how this integration first came about. According to Wallace (1990: 94): 'Between approximately 1870 and 1914 the 
Europe-centred capitalist world-econony penetrated alnust the entire globe. ${ }^{2}$ Does this also apply to North Togo? If it does, the region probably experienced certain effects of the depression set off by the crash of the New York stock market in 1929. And in case it did, what were the consequences for the inhabitants? In this section and the following, we will try to answer these questions.

When Togo became a German dependency in 1884, almost no European goods were being traded to the North, and there was no labor migration. ${ }^{3}$ There was also no production of export crops in northern Togo. Although some southbound 'sales' of livestock took place, these were not nearly large or regular enough to allow us to conclude that the process of incorporation into the capitalist world economy had begun (Hetzel,

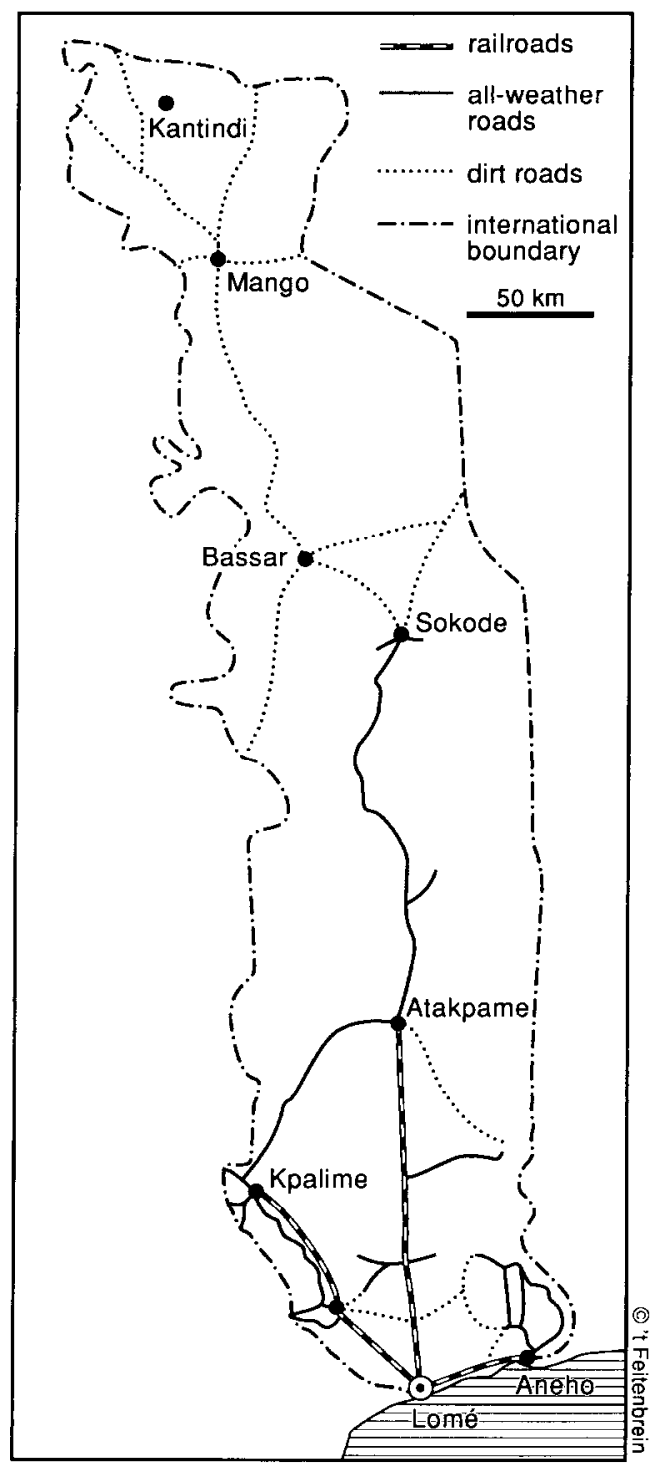

Figure 1. Togo's infrastructure in 1920. 
1974: 213; Norris, 1986: 123). ${ }^{4}$ And it was not until 1895 that North Togo was visited for the first time by Europeans (Deutsche Kolonialzeitung, 1895: 196 and 202; Markov and Sebald, 1967: 142; Bundesarcbiv, 1/82: 13).

By the turn of the century, southern Togo had gained some importance as a producer of export crops, and in subsequent years exports of palm kernels, palm oil, rubber and (after 1910 also) cocoa expanded rapidly. Whereas roads, bridges and three railroad lines were built in the South (see Figure 1), no such infrastructural improvements took place in the North. However, similar developments did occur in the southern half of the neighboring Gold Coast, with cocoa production for export receiving special attention.

Anxious to get the native population-especially people in the rather distant and inaccessible North where no export crops were produced-to work as cheap laborers on the plantations in the South and to help with the construction of roads and railroads, the Germans did what the British and French did in their colonies: they used forced labor and imposed taxes (Amenumey, 1969: 632; Bundesarchiv, 3/4058-4059 and 3/4060). Thus, the North became a 'labor reserve', whence a few hundred men were forced to migrate to southern Togo. Scores of others fled to the Gold Coast, where they found work in the cocoa-produring areas (Bundesarchin, 3/4009: 87).

As a corollary of economic development and population growth in southern Togo and the Gold Coast, demand for meat expanded there. The result was a substantial increase in livestock 'exports' from the North. According to Norris (1984: 180), the number of sheep and goats sold doubled between 1908 and 1912, while the number of marketed cattle increased about tenfold.

By 1914, the year Germany lost effective control over its West African colony, Togo as a whole was a typical 'colony of exploitation', with the South producing export crops, and the North providing some cheap labor and livestock. At that time, fewer than 400 Europeans resided in Togo (Kuczynski, 1939: 363). North Togo's links with the global economic system were indirect: either by way of the Gold Coast or via southern Togo. The region itself was still barely accessible, and the overwhelming majority of its population lived outside a money-economy-largely unaffected by colonial capitalism (De Haan, 1988: 89-90).

Considering the different economic roles to which the North and South had become subjugated, Togo's economic geography around 1914 resembled to some degree Wallerstein's model of three production zones (Wallerstein, 1976b:46-47). According to this model, the coastal zone produced for the world market; the adjacent inland zone produced food crops for workers in the coastal zone and in urban areas; and a more extensive zone, farther inland, exported manpower to the coastal zone (and to a very small extent also to the intermediate zone), while sustaining itself largely on subsistence agriculture. The resemblance was far from perfect, partly because the middle zone-central Togo-was too sparsely populated to allow much surplus food to be produced. Furthermore, by 1914 , still very few northerners migrated to the coastal region. This changed after 1920, resulting in Togo's zonal arrangement of economic activities taking on greater likeness with Wallerstein's model (see below, especially Note 5).

After Germany's defeat in World War I, the League of Nations divided Togo into two mandate territories. The western part (or British Togoland) eventually became integrated with the Gold Coast, and the eastern part (French Togoland) became administered by France. From that moment (1919) until the year of the stock market crash, the 'development' (or 'peripheralization', if you wish) of North Togo proceeded roughly along the same lines as it had prior to 1914. Its function as a labor reserve became more pronounced. Although reliable information on numbers of migrants is not available, it 
seems fairly certain that during the late 1920 s at least several hundred men were working elsewhere in Togo, mainly on infrastructural projects and plantations. Many others took advantage of the booming cocoa production in the Gold Coast, where both the tonnage and value of cocoa exports more than doubled between 1919 and 1929. In addition, a growing number of migrants from the North trekked to cocoa-producing areas in British Togoland, while others were coerced to work as porters (head-loaders) during the rainy season when roads were not only impassable for motorized vehicles but also for hand wagons (Archives Nationales du Togo, 8/10/11; Kruithof and Wijkstra, 1984: 23; Marguerat, 1986). Based on fragmentary and imprecise information, our best estimate is that by 1929 approximately eight percent of North Togo's male population aged 15-35 worked outside the area for at least part of the year-far more than in 1919 or 1914.

In the meantime, sales of northern livestock to the Gold Coast and British Togoland expanded while the cocoa boom lasted (Arcbives Nationales du Togo, 4/11). By contrast, sales of export crops from the North were still negligible by 1929 . French efforts to encourage the production of cotton and other cash crops had as yet been unsuccessful (Archives Nationales du Togo, 4/8/10/11/13).

\section{The Great Depression}

The downswing which the world economy experienced following the Big Crash of 1929 had a negative impact on the 'development' of North Togo and on the well-being of its population in at least five ways:

1. A decline in Togolese exports, and thus in export revenues, caused a serious shortage of monetary resources. Since France was unwilling to pump extra funds into Togo-after all, it was only a mandate territory, rather than a colony-French authorities in Togo tried to recover the losses by exacting higher taxes from the native population (Arcbives Nationales $d u$ Togo, 13). The ensuing 'forced' labor, often associated with the periodic absence of young adult males, caused numerous households to become disrupted. Other households fled or went into temporary hiding because they were unable to earn enough cash to make the required tax payments.

2. The value of Togo's internal trade declined as well. Because this trade was heavily taxed by the French, government revenues dropped even more (Archives Nationales du Togo, 11/33). As a consequence, funds for infrastructural improvements dried up. Most important for the purposes of this paper was that the planned extension of the railroad line from Atakpame to the North was not realized. Thus, the process of opening up the North was temporarily halted, so that the region's possibilities to commercialize its agriculture and produce export crops were reduced, or at least postponed. In fact, anbitious plans by the French to transform parts of the North into cotton-growing areas were scrapped in 1931 (Archives Nationales du Togo, 4/8/10/11/13), and efforts to raise the (forced) production of peanuts were not particularly successful until after 1935 (Archives Nationales du Togo, 27; Rey, 1975: 244).

3. Paid work on the southern plantations and in the city of Lomé also declined as a result of the economic crisis (Rapport Annuel, 1935 through 1938). With fewer opportunities to earn money in the South, the flow of labor migrants from the North receded. By and large, this situation of relative stagnation did not improve much until after World War II.

4. As a result of the depression, demand for cocoa dwindled and world-market prices dropped. This signalled the end of the cocoa boom in the Gold Coast (and British Togoland), causing Togolese labor migrants to return to their native villages (Archives 
Nationales du Togo, 11; Rappont Annuel, 1931). Thus, many households lost an important source of cash income. Even though income data are not available, we can safely assume that per capita income in North Togo was notably lower during than prior to the Great Depression. (According to Amin (1973: 120), per capita GDP for Togo as a whole was lower in 1948 than in 1920.)

5. The crisis in the cocoa industry in the Gold Coast (and British Togoland) affected northern Togo in yet another way. With profits declining and standards of living falling there, meat consumption in these areas diminished as well. And this in turn meant a reduction in livestock exports from North Togo (De Haan, 1988: 110).

\section{Conclusions and reflections}

The severity and length of the Great Depression can be explained in part by the worldwide economic interdependence that existed at the time. The fact that it had repercussions for the well-being of the rural population of North Togo is proof that by 1929 this remote and rather backward corner of Africa had become involved-to some degree at least-in the capitalist world economy. Fifteen years earlier, however, interaction with the outside world was still too limited to allow us to conclude that the region formed an integral part of the world economy (see Wallace's statement quoted above).

Since North Togo in the late 1920 s played a role in the global economic system, it could benefit from international economic upswings. On the other hand, it had become vulnerable to worldwide economic slumps. It is not surprising, therefore, that the 1929 crisis - set off by misplaced optimism among investors and speculators in the United States and other advanced countries-could have harmful effects on North Togo.

In some respects, the Great Depression temporarily halted, or even reversed, North Togo's becoming involved in the world economy. This was certainly the case during the first few years. But in other respects, it soon had the opposite effect. Faced with losses of revenues and reluctant to see their mandate territory become a serious liability (see above), the French levied higher taxes, thus forcing more inhabitants of North Togo to search for paid work outside their villages. This way, they made a larger contribution than ever before to Togo's infrastructural and economic development (e.g., Cornevin, 1969; Hallard, 1969; Rey, 1975; Archives Nationales du Togo, 4/10/11/13/14/35/40). And by withdrawing manpower from the North, while at the same time 'imposing' a money-economy on the villagers, these measures partly undermined the self-sufficient, pre-capitalist way of life of the local communities. The long-term consequence was that North Togo became increasingly penetrated by, and dependent on, the expanding world system.

Given that many remote areas in Africa and elsewhere in the Third World have experienced similar developments since the beginning of the 20th century-or since the (near-worldwide) depression of the 1930s-we can only agree with Wallerstein and others that today the world economic system does encompass the entire globe, including the most remote and least-developed places.

Wallerstein (1976b) has described the process of Africa's incorporation into the capitalist world economy in terms of three stages. During the first stage, 1750-1900, all Africa became peripheralized and, except for Liberia and Ethiopia, lost its sovereignty. The second stage of incorporation, 1900-75, was characterized by export production of crops and mineral resources, based on the exploitation of low-cost labor. According to Gutkind and Wallerstein (1976: 14), the third stage, since 1975, is one which presents Africa with a major challenge: dependent development or revolutionary transformation. For this latest 
stage, Wallerstein foresees that the truly peripheral areas, such as North Tugo, will 'bear the brunt of death from famine. . . [and] the disintegration of. . . the so-called subsistence sector' (Wallerstein, 1976b: 49).

The date, 1900, which Wallerstein uses for marking the start of stage two, appears to be quite accurate for southernmost Togo, but not for North Togo. There, it started about 25 years later, and then only if we base this conclusion on the exploitation of cheap labor and sales of livestock, rather than on the production of export crops. ${ }^{5}$ In case we do choose the latter-in North Togo: the production of peanuts-as the crucial parameter for determining the beginning of Wallerstein's second stage, then the date moves up another 12 years or so, to the late 1930s. (Incidentally, commercial production of cotton in North Togo did not gain significance until the 1970s-more than a decade after Togo had achieved independence-at roughly the same time that North Togo switched from being a net exporter of food to a net importer!)

While agreeing with Frank (e.g., 1966), Rodney (1972), Amin (1976), Szentes (1976), Peet (1991) and many others that the Third World's present crisis must be understood in terms of its dependent and subordinate position in the world economy, we wonder what a seemingly unavoidable further incorporation into the global capitalist system in future years may hold in store for North Togo. Will it be increased peripheralization, disintegration and starvation, or could it possibly lay the foundation for a brighter future?

The answer clearly depends in no small measure on the nature of the yet to be established ties with the outside world. Theoretically, increased interdependence could have beneficial effects on northern Togo, especially if substantial aid donations by the world's core countries were to result in a net inflow of capital and know-how, structural improvements, and a better utilization of human and natural resources, and all this were to be accompanied by a sharp reduction in the rate of population growth. But even if such changes began to take place tomorrow, living conditions would not improve immediately. On the contrary, the quality of life - as much as the quality of the environment-can be expected to decline for years to come. Not only is it difficult to reverse existing trends, but vested interests are known to be exceedingly persistent because they are protected with vehemence. This explains our fear that Togo's national élite in 'semiperipheral' Lomé-which enjoys a dominant position vis-à-vis the weak and dependent North Togolese periphery-will endeavor to maintain its control over North Togo. Or worse, since the present political and economic power-holders benefit from it, they may well try to strengthen this unequal (or asymmetric) relationship, thus enabling themselves to practice a form of 'internal imperialism' which favors them at the expense of the northern periphery

In other words, because it implies closer links with the national decision-makers in the country's capital, we are quite skeptical about the likelihood that an increase in North Togo's incorporation into the world economy will be beneficial to the region and its people - at least not in the short run, while the country lacks a democratic government. Whether effects may be favorable in the long run, we believe, depends above all on Togo's becoming a democratic country in which the rural farm population enjoys the political representation needed to come up for its rights and defend its interests. As suggested by Wallerstein (1976b), this may require political revolution. The increasingly loud demands for political pluralism and free elections in a growing number of African countries seem to suggest that we may be witnessing the first episode of such revolutionary change this very moment. 


\section{Acknowledgements}

We wish to thank Christian Smid and Hans de Visser of 't Feitenbrein for their artwork; three anonymous referees for their useful suggestions and constructive critiques; and editor Peter Taylor for his understanding and encouragement.

\section{Nutes}

1. Besides the best-known and most sophisticated conceptualization of the world as a single global system, that of Wallerstein, there are others. Some of these, e.g., those of Kapp (in 1845) and List (in 1851), were conceived nearly 150 years ago (see Frank, 1979; Hoekveld, 1987). Others, such as the one by Modelski, are of more recent origin (see Taylor, 1985: 51-54 for a critique of Modelski's model). Of particular interest to gengraphers is Terlouw (1989), as it contains eight world maps of different 'regionalizations' of 'the' world system. A one-world view of sorts may also be found in Van Loon (1932). This is not the place to discuss the various one-world models, all the less so because the present paper is concerned more with what they have in common-the view that there is one globe-spanning, integrated network of (economic) relations-than with their differences. In other words, our objective is not to challenge or establish the adequacy of a particular model (e.g., Wallerstein's), but to make a more general point about the (timing of the) integration of a particular African area into global circuits of production and exchange.

2. A variant of Wallace's observation is the following one by Chirot (1986: 92): 'By the end of the nineteenth century the West had completed the construction of what amounted to a vast world system encompassing all of the globe except for a few remote and thinly populated zones'. As will become clear shortly, northernmost Togo in 1900 was one such remote area, even though it was not particularly sparsely populated, having an estimated overall density of approximately 10-15 persons per sq. km. (i.e., higher than in much of central Togo). Wallerstein's view on the timing of Africa's incorporation into the world economy will be considered in the final section of this article.

3. The slave trade, of course, represented a form of integration in the world economy. However, apart from the fact that this trade had come to a halt prior to 1884-85 (Berlin Conference), it is fairly certain that North Togo never was important as a supplier of slaves.

4. Since the exported livestock was marketcd and consumed in the more densely populated areas of the southern Gold Coast and southern Togo, this trade only had significance for regional integration; not for integration at the global level. Furthermore, most of the livestock was not sold by northern farmers, but by a minority of semi-nomadic Fulani (in Frcnch: Pcul).

5. According to Wallerstein (1976b: 46-47), a three-zone arrangement of production emerged during the second stage of Africa's involvement in the world economy (see above). Togo's economic geography approached this spatial pattern most closely between approximately 1925 and 1970. However, there were several major deviations: (1) the second zone never played a role as a producer of food for the first (coastal) zone; (2) the second zone did export labor to the first zone; (3) just about all the food needed in the first zone was produced locally; (4) very gradually, parts of the second zone became producers for the world market (e.g., cocoa), thus becoming extensions of the first zone; (5) contrary to the model, the third zone was a provider of food, chiefly in the form of livestock, to the first zone; and (6) from the late 1930 s until about 1980 , Togo's third zone produced peanuts for overseas markets. Since the 1970s, new deviations from Wallerstein's model pattern have developed: (1) zones two and three have become producers of cotton for the world market; and (2) today, North Togo's entire peanut production is no longer exported, but consumed in the South. It goes without saying that the above conclusions are predicated upon where one draws the lines delimiting the three zones. For Togo, we have drawn the zonal boundaries such that they coincide roughly with the parallels of $8^{\circ}$ and $10^{\circ}$ North.

\section{References}

AMENUMEY, D. (1969). German administration in Southern Togo. Journal of African History 10, 623-639. AMIN, S. (1973). Neocolonialism in West Africa. Harmondsworth: Penguin African Library. 
Amriv, S. (1976). Unequal Development: An Essay on the Social Furmatioras of Peripheral Capitalism. New York: Monthly Review Press

Archives Nationales du Togo (no date). Affaires Politiques et Administratives. Rapports Périodiques des Cercles; Cercle de Mango Reference code: ANT 2 APA (with reference numbers). Archive in Lomé (publisher unknown).

Bundesarchiv Bundesrepublik Deutschland (no date). Deutsche Kolonialverwaltung; Fond Allemand. Reference code: BR $150 \mathrm{FA}$ (with reference numbers). Archive in Coblenz (publisher unknown).

Снirot, D. (1977). Social Change in the Twentieth Century. New York: Harcourt Brace Jovanovich.

Chirot, D. (1986). Social Change in the Modern Era. San Diego: Harcourt Brace Jovanovich.

Cornevin, R. (1969). Histoire du Togo. Mondes d'Outre-Mer, Série Histoire. Paris: Berger-Levrault.

DE HAAN, L. J. (1988). Onerbeid en regionale integratie van de savanne in Togo 1885-1985: Infrastructuur, marktintegratie, arbeidsmigratie en de lokale bestaanswijze. Amsterdam: Koninklijk Aardrijkskundig Genootschap.

Deutsche Kolonialzeitung (1895). Organ der Deutschen Kolonialgesellschaft. Berlin: Deutsche Kolonialgesellschaft.

Frank, A. G. (1966). The development of underdevelopment. Montbly Review 18, 17-31.

Frank, A. G. (1979). Dependent Accumulation and linderdenelopment. New York: Monthly Review Press.

Gutkind, P. C. W. AND Wallerstein, I. (1976). Introduction. In The Political Economy of Contemporary Africa (P. C. W. Gutkind and I. Wallerstein eds) pp. 7-29. Beverly Hills: Sage.

HaLlaRD, J. N. (1969). Une action de développement intégré dans le Nord-Togo (1967-1968). L'Agronomie Tropicale (Série II: Agronomie Générale-Etudes Techniques) 29, 463-504.

HET7Ed, W. (1974). Studien Zur Geographie des Handels in Togo und Dabomey. Kölner Geographischen Arbeiten. Köln: Geographisches Institut der Lniversität Köln

Hofкve. , G. A. (1987). Het wereldsysteem, terrein van onverhulde ideologie. In Regio's in Wereldcontext: Ontuikketingen in bet wereldsysteem en in macro-regio's (G. A. Hoekveld and L. Van de Laan eds) pp. 29-44. Meppel: Edu'Actief.

KruITHOF, A. C. AND WiJkstra, J. (1984). Oterbeid en Landbouw: Een vergelijking tussen Gharut en Ivoorkust. Unpublished MA thesis, University of Amsterdam, Department of Human Geography.

KuCZYNSK, R. (1939). The Cameroons and Togoland: A Demographic Study. London: Oxford University Press.

Marguerat, Y. (1986). Deux cent cinquante-quatre cousins; une étude en cours sur les migrations d'une lignage kabyè. In Migrations Togolaises, bilan et perspectives (E. Le Bris, G. Pontié, A. Quesnel, J. Gregory, M. Duquette-Ahado and K. Vignikin eds) pp. 85-108. Lomé: Université du Bénin, Unité de Recherche Démographique.

MARKO', W. AND SEBALD, P. (1967). The treaty between Germany and the sultan of Gwandu. Journal of the Historical Society of Nigeria 4, 141-151.

NorRIs, E. G. (1984). The Hausa kola trade through Togo, 1899-1912: some qualifications. Paideuma 30, 162-184. Norris, E. G. (1986). Atakora Mountain refuges: systems of exploitation in northern Togo. Anthropos 81, $109-136$.

PEET, R. (1991). Global Capitalism: Theories of Societal Development. London: Routledge.

Rapport Annuel du Gouvernement Français au Conseil de la Société des Nations sur l'Administration sous Mandat du Terriloire du Togo (1931 and 1935-1938). Paris: Larose Editeurs.

Rky. P. Pr. (1975). Les formes de la décomposition des sociétés vers les zones de capitalisme agraire. In L'Agriculture africaine et le capitalisme (S. Amin ed.) pp. 233-256. Paris: Anthropos-Idep.

Rodney. W. (1972). How Europe Underdeveloped Africa. London: Bogle-l'Ouverture Publications, and Dar es Salaam: Tanzania Publishing House.

Szentes, T. (1976). The Political Economy of Underdevelopment, 3rd edn. Budapest: Akadémiai Kiadó.

TAYLOR, P. J. (1985). Political Geography: World-Economy, Nation-State and Locality. London: Longman.

TAYLOR, P. J. (1986). The world-systems project. In A World in Crisis? Geograpbical Perspectives (R. J. Johnston and P. J. Taylor eds) pp. 269-288. Oxford: Basil Blackwell.

TAnok, P. J. (1988). World-systems analysis and regional geography. The Professional Geographer 40, 259-265.

Terlouw, C. P. (1989). World-system theory and regional geography. Tijdscbrift voor Economiscbe en Sociale Geografie 80, 206-221.

VAN Loon, H. W. (1932). Van Loon's Geography: The Story of the World We Live in. New York: Simon and Schuster.

WhLACE, I. (1990). The Global Economic System. London: Unwin Hyman.

WallersteIn, 1. (1976a). A world-system perspective on the social sciences. British Joumal of Sociology 27, $345-354$.

WAllerstein, 1. (1976b). The three stages of African involvement in the world-economy. In The Political Economy of Contemporary Africa (P. C. W. Gutkind and I. Wallerstein eds) pp. 30-57. Beverly Hills: Sage

WalleRSTEIN, I. (1979). The Capitalist World-Economy. Cambridge: Cambridge University Press. 